IZA DP No. 5724

Religiosity and Migration:

Travel into One's Self versus Travel across Cultures

Mariya Aleksynska

Barry R. Chiswick

May 2011 


\title{
Religiosity and Migration: Travel into One's Self versus Travel across Cultures
}

\author{
Mariya Aleksynska \\ CEPII, FRdB \\ Barry R. Chiswick \\ George Washington University \\ and IZA \\ Discussion Paper No. 5724 \\ May 2011 \\ IZA \\ P.O. Box 7240 \\ 53072 Bonn \\ Germany \\ Phone: +49-228-3894-0 \\ Fax: +49-228-3894-180 \\ E-mail: iza@iza.org
}

Any opinions expressed here are those of the author(s) and not those of IZA. Research published in this series may include views on policy, but the institute itself takes no institutional policy positions.

The Institute for the Study of Labor (IZA) in Bonn is a local and virtual international research center and a place of communication between science, politics and business. IZA is an independent nonprofit organization supported by Deutsche Post Foundation. The center is associated with the University of Bonn and offers a stimulating research environment through its international network, workshops and conferences, data service, project support, research visits and doctoral program. IZA engages in (i) original and internationally competitive research in all fields of labor economics, (ii) development of policy concepts, and (iii) dissemination of research results and concepts to the interested public.

IZA Discussion Papers often represent preliminary work and are circulated to encourage discussion. Citation of such a paper should account for its provisional character. A revised version may be available directly from the author. 
IZA Discussion Paper No. 5724

May 2011

\section{ABSTRACT \\ Religiosity and Migration: Travel into Ones' Self versus Travel across Cultures}

This paper examines differences in religious behaviors of the native born and immigrants in Europe, measured as self-reported religiosity, frequency of praying, and frequency of church attendance. Using the European Social Survey, we first show that, on average, religiosity of immigrants is higher than that of the native born, even among those without a religious affiliation. We test hypotheses that can explain these observations. Differences in individual characteristics, such as age, education, income, marital status, and notably denominations, partly account for the overall differences. Religiosity of immigrants declines with duration in the destination. Both origin and destination country characteristics, such as economic development, religious pluralism, religious freedom, and societal attitudes towards religion are important predictors of religiosity. These external factors are able to fully explain the difference in church attendance between immigrants and the native born.

JEL Classification: F22, J61, N3, Z12

Keywords: economics of religion, religiosity, immigrants, secularization, culture, integration

Corresponding author:

Barry R. Chiswick

CCAS - Economics Department

George Washington University

2115 G Street, NW

Washington, DC 20052

USA

E-mail: brchis@gwu.edu

\footnotetext{
* The views expressed in this paper are those of the author(s) and do not necessarily represent those of the CEPII, George Washington University, or IZA.
} 


\section{Introduction}

Secularization has become a universal feature of the European societies over the past century (Davie, 2000). While Europeans progressively diminish not only church attendance, but even mere affiliation to any religion, concerns have been expressed about different religious behavior of immigrants ${ }^{1}$. These concerns translate into vivid political and social debates about cultural, and more specifically, religious integration of immigrants, and even lead to banning the construction of minarets in Switzerland in 2009, as well as banning public appearance in full Islamic face veil in Belgium and in France in 2010.

Much of these debates presume that immigrants' religious behavior is inherently different from that of the native born, and, importantly, particularly rigid and persistent over time. Some of the recent economic research also pointed in this direction, documenting a strong persistence of religious identity (Bisin and Verdier, 2000), and of immigrants’ religious identity in particular (Bisin et al., 2008)².

The purpose of this paper is to advance the literature on the religiosity of immigrants in Europe, and to examine closer the hypothesis of religiosity’s persistence.

We show that immigrants indeed have an overall higher degree of religiosity than the native born within the same religious denomination, and even among individuals without a religion. We propose several explanations to this observation.

First, we suggest that differences in certain individual characteristics between immigrants and the native born may translate into differences in religiosity. Immigration represents an important moment in the life of an individual, and, hence, higher religiosity may be a natural response to a profound life change caused by migration ${ }^{3}$. Church attendance as a social expression of religiosity may also be an

\footnotetext{
${ }^{1}$ In this paper, the term "church” is used to refer to any place of religious worship, regardless of the religion.

${ }^{2}$ The literature leaves open the question of overall potentially different assimilation patterns for Muslim immigrants. For most recent studies, see Constant et al. (2006) and Manning and Roy (2010) for a debate.

${ }^{3}$ There may also be immigrants' selection in terms of religiosity: only more religious individuals migrate. Such selection, however, is not likely to take place in a systematic way. High religiosity may not be an easily transferable component of an individuals' human capital as it may have a low value at a secularized destination and may penalize an immigrant. Thus, prospective immigrants,
} 
essential response to the need to establish new networks. If this proposition is true, we expect to observe a decreasing necessity of resorting to religiosity with longer duration at destination. Such a decline, however, may additionally reflect a certain convergence of behavior of immigrants to that of the native born.

Second, we hypothesize that religiosity can change under the influence of external factors and settings. We show that origin country's characteristics, such as economic development, former communist past, religious freedom and societal attitudes towards religion continue to determine individual religiosity even after migration, suggesting that culture transmission may be taking place and that religiosity indeed has certain persistence. However, we also find that the role of destination country characteristics is paramount: religious pluralism, religious freedom, and societal attitudes towards religion at the destination determine religiosity of immigrants in a manner largely similar to that of the native born. Moreover, we show that these origin and destination country characteristics are fully able to account for the difference in church attendance between immigrants and the native born.

Understanding differences in religiosity between immigrants and the native born is important for at least two reasons. First, it is vital to have a clear picture of religiosity's differences in light of the debates on acceptance, tolerance, and integration processes of immigrants. Second, religion itself has been shown to predict numerous individual outcomes, such as education (Lehrer, 1999, 2004), employment prospects (Bisin et al., 2011), earnings (Chiswick and Huang, 2008), economic and policy preferences and attitudes (Guiso, Sapienza, Zingales, 2003; Benabou and Tirole, 2006), health and wellbeing (Regnerus, 2003; Chiswick and Mirtcheva, 2010; Connor, 2010), to name a few (see Lehrer, 2010 for an overview). Understanding differences in religiosity may thus help shed light on differences in these outcomes between immigrants and the native born.

unless they are scholars or preachers of a religion, should be discouraged from significant investments valued only at the origin, such as higher religiosity. Therefore, while persecuted religious minorities in an origin may have an incentive to emigrate, active members of a dominant religious group in an origin would be less inclined to emigrate to an alien religious culture. For an overview of the economics of immigrant religious adjustment, see C. Chiswick (2003). 
The rest of the paper is organized as follows. Section 2 provides the theoretical setting for the analysis of religiosity. Section 3 describes the data to be studied, the European Social Survey (ESS) and the Association of Religion Data Archives data (ARDA). Section 4 discusses empirical strategy and results, as well as their robustness. The last section concludes.

\section{Determinants of Religious Outcomes: What Makes Immigrants Different?}

\subsection{Individual Determinants of Religiosity}

Religiosity and religious behavior have multiple facets and can be analyzed from several perspectives, such as self-reported degree of religiosity, church attendance, the frequency of praying, donating money to church activities, the extent of belief or of devotion. In this paper, we study the first three aspects of religiosity separately, allowing various socio-economic factors to influence them in a differentiated way. The degree of religiosity and praying refer to private aspects of religiosity, to personal experiences and feelings. In contrast, church attendance, being an observed social, public, activity, combines to a greater degree the notions of human and social capital, and additionally reflects the need for a ritual, and an institutional attachment (Davie, 2000). The two types of religiosity, private and public, may be affected in a different way by life circumstances, such as migration.

There are various reasons why individuals may be religious. Paraphrasing Azzi and Ehrenberg (1975) and Iannaccone (1990), religion may comprise three goods: an afterlife good, a spiritual good, and a social good. Religion has the "salvation motive”, and it provides benefits that extend beyond life's limits. It also gives satisfaction and psychological comfort by helping answer important life questions. Networks created through religious practice, in addition to allowing socialization, giving access to the marriage market, and helping to educate children in the norms and values of this denomination, may also satisfy more materialistic needs, such as providing social insurance benefits, helping in hardships, finding employment, or creating business opportunities (Stark and Finke 2000; Scheve and Stasavage, 2006). 
The literature suggests numerous factors that may affect religious behavior of any individual, regardless of their nationality status. Among the observed regularities, age, income or social class, belonging to a minority group, and living in rural areas have been found as significant determinants of religiosity, notably measured as church attendance (Azzi and Ehrenberg, 1975). Specifically, as with many other types of social participation, age is related to religious participation in a non-linear way, with periods of declining activity observed for 30-35 year olds (the busiest time of professional development, creating families and raring small children: Alesina and La Ferrara, 2000), as well as for elderly individuals. Income, or social class, may have little impact on church attendance, but have a strong association with other types of religious behavior, such as donations (Iannaccone, 1998). In contrast, the impact of gender on religiosity is more complex, and varies across denominations: while Christian women are usually found to be more outwardly religious then Christian men, the opposite is true for Muslims and Jews (Sullivan, 2006).

\subsection{Immigration as a Personal Experience}

We expect religiosity outcomes of immigrants and of the native born to be rather different for at least three reasons. First, immigrants’ overall socio-economic characteristics are usually different from those of the native born, and these differences may translate into different religiosity and practice. If, for example, the native born are more likely to be elderly than immigrants, they may be less religious simply because religiosity tends to decrease with advanced age. One of the main individual differences is also a different religious affiliation (if any). Since average degree of religiosity may vary from one denomination to another, immigrants with a different denomination than an average native-born person may have a different average religiosity.

Differences in other individual characteristics, such as income, employment, or place of residence may also be important. As the time since migration goes by, a convergence of these characteristics between immigrants and native born in economic and social terms takes place (Chiswick, 
1978; Borjas, 1995; Green, 1999; Dustmann, 2996; Fernandez and Fogli, 2009). This convergence may translate into greater resemblance in religious behavior.

Second, immigration by itself represents a turning point in an individual's life, as it exposes an individual to a different cultural environment, and requires changes in behavior as a response to changing economic and family situations. As such, it may change individual religious behavior because a migrant may resort to religion in a particular life moment to address profound life concerns, obtain psychological comfort, or mitigate loneliness (Waite and Lehrer, 2003; Connor, 2010; Lehrer, 2010). Stark and Finke (2000) note that, along with marriage, migration is also a major factor in religion switching, reflecting social adaptation and the need to form new networks. Even those migrants who were rarely attending a church in their origin country may start doing so at a destination, in order to meet both the native born and other immigrants. Indeed, churches have been primary places for ethnic gatherings and celebrations. Oftentimes, they serve as an "island of familiar experience [...] where origin-specific skills (such as language, ritual, etiquette) can still yield benefits” (C. Chiswick, 2003). Migration networks created through religious institutions eventually play an important role in information transmission regarding economic opportunities in the receiving society (Borjas and Hilton, 1996; Mayda, 2010; Munshi, 2003), housing, schooling, and obtaining immigration-related papers (see Ebaugh and Chafetz, 2000, for an overview). They also create further opportunities for religious, civic, and community engagement (ASDC Report, 2002; Cyrus et al., 2006).

Furthermore, the sheer fact of being an immigrant and, oftentimes, a minority, can increase "the social value of religious activity [...] as discrimination may limit their [immigrants'] market consumption alternatives” (Azzi and Ehrenberg, 1975), helping to sustain a potentially different religiosity.

If these hypotheses are true, immigrants' religiosity may change as the time since migration goes by. Social, economic, and also religious adaptation in the host society may decrease the necessity of private religious practice, such as praying. Church attendance as a social expression of religiosity may 
also diminish if initial high attendance was a strategic search for networks, and if new networks outside of the church have been created. It may also, however, increase over time, if greater time at the destination gives access to greater possibilities of attendance in terms of place, time, the language of the service, and greater attachment to new religious networks.

Thus, for immigrants, the years since migration may be an important predictor of religiosity. However, given the array of the effects that may come into play over time, we would be cautious to interpret the changing religiosity as a sign of positive or negative assimilation, as is usually done in migration studies. In addition, in the case of religiosity, integration rather than assimilation may be a more desirable outcome, in which the acceptance on the part of the native born, and the right to freely exercise one’s difference matters more 4 . Immigrants may also expressively maintain their ethnoreligious identity and at the same time adapt and integrate to different degrees into the society in which they live (Ebaugh and Chafetz, 2000; Hillman, 2010).

\subsection{Religiosity, Economic Development and Culture}

Last but not the least reason for potential differences in religiosity between natives and the foreign born is the fact that immigrants come from countries that are different in terms of religious denomination, levels of religious practice, the cultural role of religion, and the societal and governmental attitudes towards the religion. Indeed, according to Gallup and Crabtree (2010), religiosity varies tremendously across the world, from very low levels in most of the developed countries, such as West European, and countries of the former Soviet bloc, to high levels in least developed countries, and in the US.

The literature offers several reasons for these cross-country differences. One of the leading hypotheses - the secularization theory - suggests a negative link between development and religiosity,

\footnotetext{
${ }^{4}$ To quote the British Home Secretary Roy Jenkins, 1966: "I do not regard [integration] as meaning the loss, by immigrants, of their own national characteristics and culture. I do not think that we need in this country a 'melting pot', which will turn everybody out in a common mould, as one of a series of carbon copies of someone's misplaced vision of the stereotyped Englishman... I define integration, therefore, not a flattening process of assimilation but as equal opportunity, accompanied by cultural diversity, in an atmosphere of mutual tolerance”. Quotation borrowed from Algan et al. (2010).
} 
predicting the decline of both religious participation and beliefs as countries advance in economic terms (Weber, 1993 [1922]; Martin, 1978). One of the reasons for this is that economic development produces numerous forms of other activities, and changes the value of time (Barro and McCleary, 2003a). Competition of religious participation and practice with secular activities reduces the time and effort devoted to the former (Gruber and Hungerman 2008). Numerous studies developed and confirmed the predictions of the secularization theory; most recent include Verweij, Ester, and Nauta (1997) and Gaskins, Golder, and Siegel (2009).

There are some countries, however, that stand out as particularly striking exceptions to the predictions of this theory, and the United States is the leading example. Here, religious belief and practice have been remarkably stable over time, and high compared to other countries at a similar level of economic development (Greeley, 1989; Stark, Iannaccone, Finke, 1996). This observation gave rise to the religious market model (Iannaccone, 1998), according to which diversity of religions and churches, or religious pluralism, increases competition for adherents. By offering "better" service, competing religion providers encourage religiosity, be it in terms of prayer, participation, or donation (Iannaccone, 1991; Finke, 1998).

Despite its appealing underlying economic reasoning, empirical tests of this model produced mixed results. For example, the measure of religious pluralism often employed in empirical work and based on Herfindahl index ${ }^{5}$ has been found to often have a negative, if any, correlation with religiosity (see Chaves and Gorski, 2001, for an overview of empirical studies). One of the reasons for this may be the fact that this measure also reflects overall tolerance and freedom of societies (Alesina et al., 2003). The latter, however, may favor all forms of religious beliefs and participation, including none. At the same time, religious freedom measured by moderate government regulation is usually found to be

\footnotetext{
${ }^{5}$ Index of religious pluralism, or fractionalization (Iannaccone, 1998; Alesina, La Ferrara, 2000) is constructed according to the formula: $\mathrm{RF}_{\mathrm{i}}=1-\sum_{k} s_{k i}^{2}$, where $s$ is a share of $k$ religion denominations in country $i$. This index is also known as one minus Herfindahl index of group shares. It measures the probability that two randomly drawn individuals in country $i$ belong to different religions. Higher values of the index represent higher religious fragmentation, and hence, heterogeneity.
} 
positively associated with religiosity, supporting the theory’s predictions (Chaves and Cann, 1992; Iannaccone, Finke, and Stark 1997; Barro, McCleary, 2003b). As an extreme example, one may consider the case of communist countries, where governments sought to fully suppress religion. As a result, these countries exhibited some of the lowest rates of religiosity (Gallup and Crabtree, 2010; Barro, McCleary, 2003a).

Provided that institutional, economic, and cultural developments in origin countries have longlasting, post-migration effects, immigrants coming from different parts of the world will be different from both the European native born and from other immigrants. In addition, cross-country differences in receiving countries may also have a differentiated impact on the religiosity of immigrants coming from the same country. In what follows, we assess the role of these home and host country effects in determining immigrants’ religiosity.

\section{Data Description}

\subsection{The Sample}

The analysis of this paper builds on the European Social Survey, which is a Europe-wide survey conducted every two years. We pool the first four rounds, covering the period 2002-2009. The survey provides information on individual socio-economic characteristics, including their religious denomination and various measures of religiosity. The survey also contains information on the individual's country of birth, allowing us to distinguish between natives and immigrants, and the length of time immigrants spent in destination countries.

The sample is restricted to individuals 16 to 70 years of age, whose country of birth is known. The sample is further restricted to individuals of Roman Catholic, Protestant, Orthodox Christian, Other Christian, Muslim, and Jewish religious denominations, and those who report they do not have a religion. The category "other religion” is omitted from the analysis, as this group is very heterogeneous and represents only $1 \%$ of the sample. We also exclude second-generation immigrants and individuals 
with one foreign-born parent from the analysis. Sample sizes of these groups of individuals are too small for a meaningful separate analysis. Lastly, we omit the native born without citizenship, as well as several destination countries ${ }^{6}$. The final sample consists of 24 European countries of residence, 84,447 nativeborn persons, defined as native-born individuals with both parents born in the country of current residence, and 7,017 first-generation immigrants (see Table A1 of the Appendix for more details).

The countries of the dataset are very heterogeneous in terms of migration histories and patterns. Approximately $40 \%$ of all immigrants come from other Western European countries, as well as from Canada, Australia, and Japan. Some countries, such as Switzerland, Germany, or Great Britain, are home to immigrants from over twenty destinations. Others, such as Eastern European countries or Russia, host immigrants from just a few, mostly neighboring countries, with the native and foreign born population of similar ethnicity. In these countries, it would perhaps be more accurate to characterize the foreignborn as "born outside of the country’s modern territory", rather than immigrants. Countries like Spain and Greece are known to be new immigration countries, and this fact is reflected in the very low proportion of immigrants with more than twenty years of residence. These differences are an important source of variation in country characteristics and in immigrant-specific characteristics that we are going to explore.

With the exception of the UK and the Netherlands, there is a certain sorting of migrants: religious affiliation of the majority of immigrants corresponds to the country's main religion in most of the destinations (Table A1 of the Appendix). However, in most of the countries, unaffiliated immigrants also outnumber immigrants with a religious affiliation. Islam often comes as a second main religion among immigrants (and even as a first religion in Nordic countries).

\subsection{Measures of Religiosity}

\footnotetext{
${ }^{6}$ Omitted are Italy, Bulgaria, Iceland, Cyprus and Turkey, for the lack of data on foreign born, as well as Israel, for its specificity with regard to the studied question. For more details on this, and on the survey in general, see www.europeansocialsurvey.org. See also Jowell et al. (various issues).
} 
Three questions measure the individual's self-reported religiosity. First is the explicit question "how religious are you", measured on the scale from 1 to 10, with higher values indicating stronger religiosity. In addition, there are also questions "how often do you pray", and "how often do you attend religious services", with responses ranging from "never" to "every day", which are converted into the days per year (see Appendix Table A2). These three measures of religiosity are used as alternative dependent variables in the regression analysis.

Self-reported measures of religiosity vary substantially among individuals with different denomination, and most dramatically between those who do and do not have a specific religious affiliation. The proportion of unaffiliated individuals in Europe is high: 44\% of the native born and 39\% of first-generation immigrants report belonging to no particular religion. Previous research has shown that this group is very heterogeneous, as it contains individuals with both particularly low and high levels of educational attainment (Keysar and Kosmin, 1995; Iannaccone, 1998), atheists, doubters, and people in search of a religion. In general, while secularization has been a common feature of European societies, it has affected primarily social aspects of religiosity, such as church attendance and donations (ibid), while, some argue, the need for a private search for spirituality has remained. In fact, Ekelund et al. (2006) suggest that in the modern societies, individuals with "no religion" are often those who are moving away from organized religion towards individualized belief systems, rather than individuals with no beliefs at all, and hence we may observe significant levels of religiosity even among these individuals.

The latter proposition is confirmed by the descriptive evidence on differences in religiosity across individuals with and without a religious affiliation, as well as between immigrants and the native born (Table 1). For both immigrants and the native born, levels of all three types of religiosity are nonnegligible among non-believers, even though they are always lower compared to individuals affiliated to a religion. On average, first-generation immigrants with and without religious affiliation have slightly higher levels of all types of religiosity compared to the native born of the same category. 


\subsection{Explanatory Variables}

To explain religiosity, three main types of independent variables are considered in the econometric analysis.

First, these are the individual socio-economic characteristics that affect religiosity regardless of the nativity status. Following previous discussion, they include age and years of education, gender, number of household members, marital status, income, employment status (employee, unemployed, or self-employed, with "out of the labor force" being the omitted group), as well as urban residence (McCleary and Barro, 2006). We also control for individual religious denominations, including none. Table A2 of the Appendix provides a full definition of these variables, and Table A3 contains descriptive statistics for both population groups.

Immigrants differ from the native born along numerous individual characteristics. For example, while there is no difference in age, in number of household members, or in household income between first-generation immigrants and the native born, immigrants on average have lower marriage rates and higher divorce rates, higher unemployment, and live in urban areas as opposed to the native born. Education levels between the two groups are largely similar; if anything, immigrants have slightly greater years of schooling. Lastly, among immigrants, there is a significantly lower share of individuals belonging to the main religious denomination of their country of residence, and a lower share of nonaffiliated individuals. There is a lower proportion of Roman Catholics and Protestants among immigrants than among natives, but a higher proportion of all other denominations. Do these differences explain differences in religiosity?

Second, for first-generation immigrants, we also control for a range of immigrant-specific variables that are standard for this type of research. These include language, citizenship status, as well as years since migration. Naturally, from Table A3, immigrants have a lower rate of speaking a language of the country as the first language at home, or being citizens. 
Third, we also consider the role of origin and destination country cultures and societal settings that may affect religiosity both through culture transmission and culture adaptation processes. These characteristics include religious fragmentation, religious freedom, and a measure of social attitudes towards other religions. Using the information on the largest religious group, we also construct a variable "belonging major", which takes the value of one if an individual belongs to the largest religious branch of the country. These data come from the Association of Religion Data Archives (ARDA). Also included are GDP per capita as a measure of development ${ }^{7}$ (World Bank Development Indicators), and a dichotomous variable for having a communist government, presently or in the past.

\section{Econometric Strategy and Results}

\subsection{The role of individual differences between immigrants and native born}

Our point of departure is the analysis of differences in religiosity between native-born and foreign-born men and women, given the differences in their individual characteristics. To this end, we estimate the following specification:

$$
Y_{i j}=\alpha_{i j}+\beta_{1 i j} X_{i}+\beta_{2 i j} \text { Immigr }_{i}+\beta_{3 i j} \text { Immigr }_{i} * Z_{i}+\varepsilon_{i}
$$

where $Y_{i j}$ is an individual's $i$ outcome of interest $j, j=$ how religious; attending religious services; frequency of praying. $X_{i}$ is the set of individual characteristics; Immigr $_{i}$ is a dichotomous variable for the first-generation immigrant, $Z_{i}$ is the set of immigrant-specific characteristics.

Tables 2 to 4 contain OLS estimation results for three alternative dependent variables measuring religiosity. The first two dependent variables - self-assessed religiosity and praying - refer to the private indicators, while the third - frequency of attendance - refers to a more extravert, social, indicator of religiosity. All three dependent variables are treated as continuous variables.

\footnotetext{
${ }^{7}$ For destination countries, GDP per capita is measured at each year of the survey. For origin countries, we use the value for 2005, which corresponds to the mid-point of the data collection. Alternatively, we tried to include the GDP measure at time of migration, with similar results.
} 
In Tables 2-4, coefficients in columns (1) are estimated for the sub-sample of the Europeans living in their native country. Across all three regressions, we observe largely similar patterns. Religiosity is related to age in a non-linear way: it first declines with age up to a certain point in midtwenties - early thirties, and then starts rising. ${ }^{8}$ Older individuals are more religious. Similarly, nonlinearities are observed also for the effect of the years of completed schooling. Self-reported religiosity decreases with education up to 10 years of formal schooling, and rises afterwards; the reversal is also observed around 13 years of schooling for praying. The effect of schooling is positive for attendance (only the square term is significant, albeit at 10\%).

On aggregate, we find that women have a higher religiosity as opposed to men ${ }^{9}$. Individuals with larger households are significantly more religious. The fact of being married is only associated with higher self-reported religiosity, but not with praying or attendance. In contrast, divorced individuals have higher levels of private religiosity, but lower rates of social religiosity, as opposed to single individuals. We also find that religiosity is related in a negative way to household income, and is also significantly affected by employment status. Notably, self-employed individuals have higher rates of private religiosity as compared to individuals out of the labor force, while unemployed have lower religiosity measured by any of the variables. Furthermore, we confirm earlier findings that native-born individuals living in urban versus rural areas have lower religiosity.

These regressions also control for the individual self-reported religious affiliation, including no affiliation at all. The benchmark category is Roman Catholics, which is one of the largest and also most homogeneous religious groups of the sample. There is a high diversity of religiosity among native-born

\footnotetext{
${ }^{8}$ From Table 2, col.1, dREL/dAge $=-0.025+0.041 *($ Age $/ 100) * 2$, so that the partial effect is at its minimum at Age $=31$ for self-reported religiosity. The partial effect is its minimum at Age $=23$ for praying (Table 3, col.1), and at Age $=27$ for attendance (Table 4, col.1).

${ }^{9}$ The gender effect is heterogeneous across denominations, however. In estimations done separately by denomination (below), we find that non-affiliated, and Christian women are more religious than men. In contrast, there is no statistically significant difference in self-reported religiosity and praying among Muslim men and women, while Muslim women have statistically significant lower attendance rate. Jewish women and men do not have different religious behavior along any of the three dimensions considered.
} 
individuals, depending on their denomination. As expected, individuals with no reported affiliation have significantly lower levels of religiosity as opposed to Roman Catholics, and as opposed to individuals of any other religious group. Protestants and Orthodox Christians, however, also have significantly lower religiosity compared to Roman Catholics, while other Christians have higher religiosity. The sample size of representatives of other denominations is relatively small to draw definite inferences; but our data suggest that there are no significant differences in religiosity of Muslims and Catholics, while Jews have lower self-reported religiosity and attendance, notwithstanding similar praying frequency.

Columns (2) of Tables 2-4 are based on the pooled-sample estimation of native and foreign born. In these columns, we distinguish only between individuals having no religious allegiance (norelig dummy), using any other religious affiliation as a comparison group. Immigrant dummy (immigr) is interacted with the norelig dummy in order to assess the differentiated effect of non-affiliation for immigrants and for the native born. Across three regressions, we find that the simple fact of being an immigrant increases the levels of religiosity, even when belonging to a religious group is controlled for. Statistically significant interaction terms on norelig and immigr dummy variables in Tables 3 and 4 coupled with the statistically significant immigr term suggest that even for individuals reporting no religious affiliation, the fact of being an immigrant amplifies religiosity. This may be due either to the selectivity in migration, or because all other individuals in the origin countries are more religious than in the destination countries, or because immigration reflects the profound life changes, and hence the need to refer to spirituality. In the latter case, greater religiosity of immigrants would be a transitory phenomenon; however, this hypothesis cannot be tested here directly, as the religiosity of individuals prior to migration is not known.

Further, in columns (3) we repeat the pooled-sample estimation, including all other immigrantspecific characteristics, such as the years since migration, language and citizenship. Private forms of religiosity have a clear tendency of decreasing over time, and this is especially true for praying, which is significantly lower for immigrants with more than 5 years of residence as compared to the newcomers. 
Despite this, private religiosity of immigrants remains overall higher than of the native born through the respondents' life. If higher religiosity of immigrants upon arrival were indeed caused by the fact of migration, the decline of private religiosity over time could reflect the diminishing need to resort to religiosity as the life gets stabilized. Otherwise, this result suggests a potential immigrant's adaptation to local customs. It may also be related to a marriage to a native-born spouse (the data do not allow to control for this directly, however). Being a citizen is associated with lower religiosity, a result that can also be interpreted as an attachment to the assimilation into the host society.

In contrast, a longer duration of residence has no particular impact on church attendance. We also note that speaking any of the official languages of the destination country at home as a first language has no association with religiosity, while citizenship is negatively associated only with self-reported degree of religiosity.

Lastly, in Tables 2-4 columns (4), a separate estimation is done for the sub-sample of immigrants. There are several differences in the impact of individual characteristics of immigrants on religiosity, as contrasted to the native born (columns 1). Notably, age does not seem to matter for immigrants ${ }^{10}$, as well as the employment status, while the income effect is positive for self-reported religiosity and insignificant for other measures. For immigrants, non-linearities of the effect of schooling are also present, as religiosity measures show a decline in religiosity with education, followed by an increase. The turning point, however, is different between immigrants and the native born. Self-reported religiosity decreases with the years of schooling up to 18 years, and increases thereafter (however, given our range of data, the positive effect is observed only for $7 \%$ of the sample of immigrants who have more than 18 years of schooling). The turning point for praying of immigrants is at 13 years of education, and at 14 years for attendance. Household size has a positive and significant effect only for immigrants’ praying (Table 3, column 4); it is positive but insignificant for two other measures.

\footnotetext{
${ }^{10}$ If we omit the square term from regressions, age has a statistically significant negative impact on praying of immigrants, and a positive impact on attendance, significant at $7 \%$.
} 
In terms of allegiance, both native and immigrant non-affiliated individuals, Orthodox Christians, and Jews have consistently lower religiosity levels than native and immigrant Catholics. In contrast, other Christians are more religious than Catholics, and hence more so than any other group, regardless of nativity. For Protestants, while lower religiosity patterns are observed among native born, no differences with Catholics are found for immigrants.

\subsection{Differences in religiosity across denominations}

As a next step, we repeat the pooled regressions for the native born and first generation immigrants by denomination. From Table 5, compared to the native born of the same group, nonaffiliated and Roman Catholic immigrants have a significantly stronger religiosity as measured by all three indicators of religiosity. For Roman Catholics, there is a particularly strong evidence of declining religiosity with duration at the destination. Among Protestants, immigrants have only a slightly higher tendency of reporting a higher religiosity, while Orthodox immigrants only pray more than Orthodox natives, and these differences remain intact with duration. There is no apparent difference between the native- and foreign-born respondents from other branches of Christianity.

Unfortunately, the sample sizes are particularly small for Muslims (252 natives and 832 immigrants ${ }^{11}$ ) and Jews (44 natives and 24 immigrants). The results for these two groups suggest that both Muslim and Jewish immigrants also have a higher religiosity as compared to the native-born individuals of similar religious groups, and that they also have a tendency to decline over time (the only exception is higher religiosity of Jews with 6 to 10 years after migration). However, given the small sample size for Jews, we are cautious to interpret these results as definitive.

\footnotetext{
${ }^{11}$ Muslim native born may be sorted differently across countries than immigrants. We check this possibility, and find that in our sample, there are no Muslim natives in Switzerland, Estonia, Finland, Luxembourg, and Norway. The largest concentration of Muslim natives is in Russia (66\%), Greece (15\%), Great Britain (3\%), and Slovenia (3\%). The largest concentration of Muslim immigrants is in Germany (13\%), the Netherlands (10\%), Switzerland (10\%), and Great Britain (9\%); Muslim immigrants are more evenly distributed across countries than Muslim natives. There are no Muslims in the Czech Republic or Hungary neither among immigrants nor among the native born.
} 


\subsection{Religiosity and Home and Host Country Characteristics}

Further, we explore the role of home and host country economic, cultural, and institutional characteristics that affect religiosity, as well as the robustness of previous results to the inclusion of these variables (Table 6).

The results for the native born (Table 6, column 1) suggest that host country characteristics are indeed important predictors of religiosity. In line with previous studies, higher GDP per capita has a negative association with all three forms of religiosity, consistently with the secularization theory (Barro and McCleary, 2003a; Verweij, Ester, Nauta, 1997). In contrast, the religious markets theory, as tested by the measure of religious fragmentation, is rejected, as suggested by the negative sign on this variable, and which is also consistent with numerous previous findings (Chaves and Gorski, 2001). However, religious freedom, which may also be viewed as the opposite of government regulation, has a positive association with religiosity, perhaps by increasing the efficiency of religion providers (Iannaccone, Finke, Stark 1997; Chaves and Cann, 1992). Social regulation has a positive effect, suggesting that societies with more conservative views and attitudes encourage religious behavior (Gaskins, Golder, and Siegel, 2009). For this variable in particular, however, the direction of causality may also be reversed: social regulation may be greater in more conservative societies. Religious minorities may feel besieged and respond by grouping together, while members of religious minorities with a weaker attainment may convert to major religion. Thus, we do not give a causal interpretation to this result. This logic is also confirmed by the coefficient on the variable belonging major which suggests that individuals sharing the main religion of the country tend to be less religious than those belonging to any other religion.

For immigrants, the results (Table 6, column 3) reveal that, for them, the same residence country characteristics have a largely similar effect as for the native born. The magnitudes of some coefficients differ, but the directions and the overall patterns are largely the same. Immigrants in countries with high religious pluralism tend to be less religious, while both religious freedom and stricter social attitudes have a positive association with religiosity. One notable exception is the impact of the GDP per capita 
variable, which is positive for personal religiosity, and insignificant for other variables. Potentially, it may reflect the "gratification" effect, especially for immigrants from poorer countries, who may feel more religious as a result of being more thankful for their better living conditions and economic opportunities. Overall, the fact that any of the destination country characteristics is of importance for immigrants is an interesting finding in itself. It suggests that religiosity is not a completely rigid trait, and that it does change under the influence of external factors, notably religious institutions and culture in which an individual is placed, as well as with duration at destination, as seen above.

From Table 6 column (3), we also note that similar country of origin characteristics also continue playing a role after migration, although their effect is much more disparate. Consistently with other studies, and across dependent variables, GDP at the origin has a negative impact on religiosity, as well as the former communist past (Barro and McCleary, 2005). Religious freedom has a positive association only with personal types of religiosity, but not with the attendance; while social attitudes at the origin only affect attendance, but not the personal religiosity.

In pooled estimation (Table 6, column 2), the variable immigr remains significantly positive for measures of personal religiosity. Personal religiosity remains persistently higher among immigrants throughout lifetime, albeit decreasing over time, even when origin and destination country characteristics are accounted for. This suggests that, while external factors are important for the individual introvert measures of religiosity, they are not fully able to account for differences between immigrants and native born. There may be other factors related to culture, education, or experience, that continue shaping the differences between natives and foreign born. It also may be the fact personal religiosity is indeed strongly affected by the personal experience of migration. Migration acts as a personal transformation process, a travel into ones' self, and experiences related to the fact of migration have a long-term effect on individual relationship with religiosity or spirituality in a broad sense.

In contrast, once we control for origin and destination effects, there is no longer any difference between immigrants and the native born in terms of church-going: the variable immigr becomes 
insignificant. Equally, there is no evidence that church-going changes with the years since migration. Individual and external factors, such as economic, cultural, and institutional are fully able to explain the differences in church-going between immigrants and the native born.

We also check the robustness of all these results to the definition of dependent variables and the estimation method. In particular, we recode the dependent variables into dichotomous variables. "How religious are you” gets a value of one if an individual reports any value of religiosity above 5, and zero otherwise. "How often do you pray" and "how often do you attend religious services” gets a value of one if an individual reports doing these activities more often than once a month. Probit estimation results are consistent with previous OLS results, but are not reported here to save the space. Some differences in these results with respect to the OLS results in Table 6 are that social attitudes and religious freedoms at origin gain positive signs for any religiosity measure. Compared to the results in Table 5, praying decreases with the years since migration for all religious denominations except Muslims, and attending also decreases significantly over time for Orthodox migrants and individuals with no religious affiliation.

\section{Conclusions}

This paper provided a Europe-wide analysis of differences in religiosity between immigrants and the native born, measured in terms of self-assessed religiosity, frequency of praying, and church attendance. According to the descriptive statistics, immigrants have higher religiosity as compared to the native born measured along these three dimensions, and regardless of their religious denomination. We suggest that, all other things equal, two main sets of explanations account for these differences.

First, there are several differences in the role of individual characteristics of immigrants in explaining religiosity, as contrasted to the native born. Both native and immigrant females have higher religiosity than males; however, this effect varies by denomination. Age and education affect religiosity of the native born in a non-linear way, with lowest levels of religiosity observed in late twenties and among individuals with 10 to 13 years of schooling. For immigrants, age non-linear effects are absent, 
while the impact of education is the lowest for 13 to 18 years of schooling, depending on the measure of religiosity.

Marital status has a strong association with religiosity of the native born, but not of immigrants (only the fact of being divorced increase the frequency of praying for immigrants). Household size has a positive and significant effect for any measure of religiosity of the native born, but only for immigrants' praying. For the native born, income has a negative association with religiosity, while for immigrants, this effect is positive for self-reported religiosity, and insignificant for other measures. Other individual characteristics seem not to matter for immigrants’ religiosity.

For immigrants, religiosity, especially in its private form (self-reported religiosity or praying), has a tendency to decline with the years since migration. This decline suggests that a certain adaptation to the life in the destination country's environment is taking place. Church attendance as a social expression of religiosity may also be an essential response to the need to establish new networks, to mitigate loneliness, and to capitalize on the origin-specific human capital even after migration. These benefits of attendance may also decline as outside options in the destination country appear for a migrant.

Second, contrary to popular perceptions, religiosity is not an absolutely rigid personal trait, but it can and does change under the influence of external economic and social factors and settings into which an individual lives. Specifically, origin countries’ characteristics continue determining immigrants’ outcomes even after migration. However, the impact of these factors is much more disparate and relatively weak as compared to the destination country characteristics, such as religious pluralism, religious freedom, and societal attitudes towards religion. These results suggest that external factors play an important role in private expressions of religiosity, in addition to personal needs and transformations caused by migration. For social expressions of religiosity, such as church attendance, external factors fully account for the religiosity differential between immigrants and the native born. These findings cast doubt on the recent restrictive measures adopted by some European governments' vis-à-vis religious 
minorities, which assume little responsiveness of immigrants to the environment in which they live, and little religious integration and adaptation. Some European governments might be trying to speed up the assimilation process, without recognizing the more general role of the existing environment in this process.

The analysis of this paper is based primarily on the European Social Survey, which covers most of the European countries. This type of analysis is particularly rare in the European setting, as many countries forbid the collection of religion data by government authorities. Thus, the analysis of the paper has an additional value-added of outlining religiosity patterns among the European native born. Moreover, it demonstrates the value of including questions on religion and religiosity in survey data.

\section{References}

Algan, Y., Dustmann, Ch., Glitz, A., Manning, A. 2010. The Economic Situation of First and SecondGeneration Immigrants in France. Germany and the United Kingdom. Economic Journal, 120(542), F4F30. 02.

Alesina, A., Devleeschauwer, A., Easterly, W., Kurlat, S., Wacziarg, R. 2003. Fractionalization. Journal of Economic Growth, 8, 155-194.

Alesina, A., La Ferrara, E., 2000. Participation in Heterogeneous Communities. The Quarterly Journal of Economics, 115(3), 847-904.

ASDC, 2002. Lessons learned about civic participation among immigrants. Technical Report. Washington Area Partnership for Immigrants Community Foundation for the National Capital Region, Washington D.C.

Association of Religious Data Archives. International Religious Freedom Data, 2005. Available at: http://www.thearda.com/Archive/CrossNational.asp. Accessed: October 2009.

Azzi, C., Ehrenberg, R.G. 1975. Household Allocation of Time and Church Attendance. Journal of Political Economy, 83, 27-56. 
Barro, R. J., and McCleary R. M., 2003(a). International Determinants of Religiosity, NBER Working Paper 10147.

Barro, R. J., McCleary, R.M. 2003(b). Religion and Economic Growth across Countries. American Sociological Review, LXVIII, 760-781.

Barro, R. J., McCleary, R.M. 2005. Which Countries have State Religions? The Quarterly Journal of Economics, 120 (4), 1331-1370.

Bénabou, R., J. Tirole. 2006. Belief in a Just World and Redistributive Politics. Quarterly Journal of Economics, 121, 699-746.

Bisin, A., Patacchini, E., Verdier, T., Zenou, Y., 2008. Are Muslim immigrants different in terms of cultural integration? Journal of the European Economic Association, 6, 445-456.

Bisin, A., Patacchini, E., Verdier, T., Zenou, Y., 2011. Ethnic Identity and Labor Market Outcomes of Immigrants in Europe, Economic Policy, 26(65), 57-92.

Bisin, A., Verdier T., 2000. Beyond the melting pot: Cultural transmission, marriage and the evolution of ethnic and religious traits. The Quarterly Journal of Economics, 115, 955-988.

Borjas, G. J., 1995. Assimilation and changes in cohort quality revisited: What happened to immigrant earnings in the 1980s? Journal of Labor Economics, 13, 201-245.

Borjas, G. J., Hilton L., 1996. Immigration and the welfare state: Immigrant participation in means-tested entitlement programs. The Quarterly Journal of Economics, 111, 575-604.

Chiswick, B., 1978. The effect of Americanisation on the earnings of foreign-born men. Journal of Political Economy, 86, 987-921.

Chiswick, B., J. Huang, 2008. The Earnings of American Jewish Men: Human Capital, Denomination, and Religiosity. Journal of the Scientific Study of Religion, 47(4), 694-709.

Chiswick, B., D. Mirtcheva, 2010. Religion and Child Health. IZA DP 5215.

Chiswick, C. U., 2003. Immigrant Religious Adjustment: An Economic Approach to Jewish Migrations. IZA Discussion Paper 863. 
Constant, A., Gataullina, L., Zimmermann, K.F., Zimmermann, L., 2006. Clash of Cultures: Muslims and Christians in the Ethnosizing process. IZA Discussion Paper 2350. Institute for the Study of Labor, Bonn.

Connor, Ph. 2010. Balm for The Soul: Immigrant Religion and Emotional Well-Being. International Migration. In Press.

Cyrus, N., Gropas, R., Kosic, A., 2006. Opportunity Structures for Immigrants’ Active Civic Participation in the European Union: Sharing Comparative Observations. POLITIS Working Paper 2. University of Oldenburg, Oldenburg.

Davie, G. 2000. Religion in Modern Europe: A Memory Mutates. Oxford: Oxford University Press.

Dustmann, C., 1996. The Social Assimilation of Immigrants. Journal of Population Economics, 9, 37-54.

Ebaugh, H. L., Chafetz, J.S., 2000. Religion and the New Immigrants. AltaMira Press: Oxford, UK.

Ekelund, R.B., Hébert, R. F., and Tolliso, R.D. 2006. The Marketplace of Christianity. Cambridge: the MIT Press.

Fernandez, R., Fogli, A., 2009. Culture: An Empirical Investigation of Beliefs, Work, and Fertility. American Economic Journal: Macroeconomics, 1, 146-77.

Finke, R. 1998. Religious Choice and Competition. American Sociological Review, 63, 761-766.

Gallup and Crabtree S., 2010. Religiosity Highest in World's Poorest Nations. Available online: http://www.gallup.com/poll/142727/Religiosity-Highest-World-Poorest-Nations.aspx. $\quad$ Accessed: January 2010.

Gaskins, B., Golder, M., and Siegel, D.A., 2009. Religiosity, Societal Development, and Political Attitudes. memo.

Chaves, M., Gorski P.S. 2001. Religious Pluralism and Religious Participation. Annual Review of Sociology, 27, 261-281.

Chaves, M., Cann, D.E. 1992. Regulation, Pluralism, and Religious Market Structure. Rationality and Society, 4, 272-290. 
Green, D., 1999. Immigrant occupational attainment: Assimilation and mobility over time. Journal of Labour Economics, 17, 49-79.

Greeley, A., 1989. Religious change in America. Cambridge, MA: Harvard University Press.

Grim, Brian J. and Roger Finke, 2006. International Religion Indexes: Government Regulation, Government Favoritism, and Social Regulation of Religion. Interdisciplinary Journal of Research on Religion, 2.

Gruber, J., Hungerman, D., 2008. The Church versus the Mall: What Happens When Religion Faces Increased Secular Competition? The Quarterly Journal of Economics, 123 (2): 831-862.

Guiso, L., P. Sapienza, L. Zingales. 2003. People’s Opium? Religion and Economic Attitudes. Journal of Monetary Economics, 50, 225-282.

Hillman, A. L., 2010. Expressive Behavior in Economics and Politics. European Journal of Political Economy, 26, 403-418.

Iannaccone, L.R. 1990. Religious Practice: A Human Capital Approach. Journal for the Scientific Study of Religion, 29, 297-314.

Iannaccone, L. R. 1991. The Consequences of Religious Market Structure: Adam Smith and the Economics of Religion. Rationality and Society, 3, 156-177.

Iannaccone, L. R. 1998. Introduction to the Economics of Religion. Journal of Economic Literature, 36, 1465-1496.

Iannaccone, L. R., Finke R., Stark R. 1997. Deregulating Religion: The Economics of Church and State. Economic Inquiry, 35, 350-364.

Jowell R. and the Central Co-ordinating Team. 2009. “European Social Survey: Technical Report”. London: Centre for Comparative Social Surveys. City University.

Keysar, A. and Kosmin, B. 1995. The Impact of Religious Identification on Differences in Educational Attainment Among American Women in 1990. Journal of Scientific Study of Religion, 34(1), 49-62. 
Lehrer, E.L. 1999. Religion as a Determinant of Educational Attainment: An Economic Perspective. Social Science Research, 28, 358-379.

Lehrer, E.L., 2004. Religiosity as a Determinant of Educational Attainment: The Case of Conservative Protestant Women in the United States. Review of Economics of the Household, 2(2), 203-219.

Lehrer, E. L., 2010. Religion, Human Capital Investments and the Family in the United States. In: The Oxford Handbook of the Economics of Religion, (Ed): McCleary R.

Manning, A., Roy S., 2010. Culture clash or culture club? National identity in Britain. Economic Journal, 120, F72-F100.

Martin, D. 1978. A General Theory of Secularization, Oxford, Basil Blackwell.

Mayda, A. M., 2010. International migration: A panel data analysis of the determinants of bilateral flows. Journal of Population Economics, 23, 1249-1274.

McCleary, R., Barro R. J., 2006. Religion and Economy. Journal of Economic Perspectives, 20(2), 49-72.

Munshi, K., 2003. Networks in the modern economy: Mexican migrants in the U.S. labor market. The Quarterly Journal of Economics, 118, 549-597.

Regnerus, M.D., 2003. Religion and Positive Adolescent Outcomes: A Review of Research and Theory. Review of Religious Research, 44, 394-413.

Scheve, K., and Stasavage, D. 2006. Religion and Preferences for Social Insurance. Quarterly Journal of Political Science, 1, 255-286.

Stark, R., Iannaccone, L., Finke, R. 1996. Religion, Science, and Rationality. The American Economic Review Papers and Proceedings, 86 (2), 433-437.

Stark, R., Finke, R. 2000. Acts of Faith: Explaining the Human Side of Religion. Berkeley: University of California Press.

Sullins, D. 2006. Gender and Religion: Deconstructing Universality, Constructing Complexity. American Journal of Sociology, 112, 838-80. 
Waite, L. and Lehrer, E.L. 2003. The Benefits from Marriage and Religion in the United States: A Comparative Analysis. Population and Development Review, 29(2): 255-275.

Weber, Max. 1993 [1922]. Sociology of Religion. Boston: Beacon Press.

Verweij, J., Ester, P., Nauta R. 1997. Secularization as an Economic and Cultural Phenomenon: A CrossNational Analysis. Journal for the Scientific Study of Religion, 36, 309-324.

World Bank, 2006. World Bank Development Indicators Database. Available at: http://www.worldbank.org Accessed: March 2010. 
Table 1. Variation of Religiosity (Percent) across Religiousness and Immigrant Status

\begin{tabular}{|c|c|c|c|c|}
\hline & \multicolumn{2}{|c|}{ Native born } & \multicolumn{2}{|c|}{ Foreign born } \\
\hline & No religion & $\begin{array}{l}\text { Belongs to a } \\
\text { religion }\end{array}$ & No religion & $\begin{array}{c}\text { Belongs to a } \\
\text { religion }\end{array}$ \\
\hline \multicolumn{5}{|l|}{ Degree of religiosity: percent of individuals } \\
\hline Low (scale 0 ) & 31,39 & 1,76 & 27,84 & 2,01 \\
\hline Moderate (scale 1-4) & 53,45 & 42,08 & 49,13 & 36,05 \\
\hline High (scale 5-10) & 15,16 & 56,16 & 23,03 & 61,94 \\
\hline Total & 100 & 100 & 100 & 100 \\
\hline Average value (scale $0-10$ ) & 2,61 & 5,89 & 3,22 & 6,35 \\
\hline \multicolumn{5}{|l|}{ Frequency of praying: percent of individuals } \\
\hline Low (never) & 69,97 & 16,21 & 57,68 & 12,58 \\
\hline Moderate (special holidays, or rarer) & 18,28 & 24,07 & 21,49 & 21,81 \\
\hline High (once a month or more often) & 11,75 & 59,72 & 20,83 & 65,61 \\
\hline Total & 100 & 100 & 100 & 100 \\
\hline Average value(scale 0 -10) & 17,13 & 124,58 & 37,36 & 153,39 \\
\hline \multicolumn{5}{|c|}{ Attendance of religious service: percent of individuals } \\
\hline Low (never) & 63,50 & 13,88 & 58,96 & 15,70 \\
\hline Moderate (special holidays, or rarer) & 33,30 & 45,44 & 36,11 & 45,62 \\
\hline High (once a month or more often) & 3,20 & 40,68 & 4,93 & 38,68 \\
\hline Total & 100 & 100 & 100 & 100 \\
\hline Average value(scale 0 -10) & 1,77 & 20,99 & 2,68 & 23,03 \\
\hline Percent of sub-sample & 42,20 & 57,80 & 37,56 & 62,44 \\
\hline
\end{tabular}


Table 2. Analysis of Religiosity: How Religious Are You?

\begin{tabular}{|c|c|c|c|c|c|c|c|c|}
\hline \multirow[t]{3}{*}{ Variables } & \multirow{2}{*}{\multicolumn{2}{|c|}{$\begin{array}{c}\text { Native born } \\
(1) \\
\end{array}$}} & \multicolumn{4}{|c|}{$\begin{array}{c}\text { Native born + First generation } \\
\text { immigrants }\end{array}$} & \multirow{2}{*}{\multicolumn{2}{|c|}{$\begin{array}{c}\begin{array}{c}\text { First generation } \\
\text { immigrants }\end{array} \\
(4) \\
\end{array}$}} \\
\hline & & & ( & & ( & & & \\
\hline & $-0.025^{* *}$ & $(0.006)$ & $-0.010^{*}$ & $(0.004)$ & $-0.021^{* *}$ & $(0.006)$ & 0.030 & $(0.027)$ \\
\hline Age squared/100 & $0.041 * *$ & $(0.007)$ & $0.025^{* *}$ & $(0.004)$ & $0.035 * *$ & $(0.007)$ & -0.037 & $(0.029)$ \\
\hline Education years & $-0.042 * *$ & $(0.014)$ & $-0.090 * *$ & $(0.009)$ & $-0.077 * *$ & $(0.013)$ & $-0.181^{* *}$ & $(0.044)$ \\
\hline Education squared & $0.002^{* *}$ & $(0.001)$ & $0.003^{* *}$ & $(0.000)$ & $0.003^{* *}$ & $(0.000)$ & $0.005^{* *}$ & $(0.002)$ \\
\hline Female & $0.628 * *$ & $(0.026)$ & $0.695^{* *}$ & $(0.016)$ & $0.602 * *$ & $(0.026)$ & $0.463^{* *}$ & $(0.106)$ \\
\hline $\mathrm{N}$ hh members & $0.126 * *$ & $(0.013)$ & $0.097^{* *}$ & $(0.007)$ & $0.132 * *$ & $(0.012)$ & 0.079 & $(0.042)$ \\
\hline Married & $0.220 * *$ & $(0.038)$ & $0.187 * *$ & $(0.024)$ & $0.203 * *$ & $(0.038)$ & -0.043 & $(0.159)$ \\
\hline Divorced & $0.185 * *$ & $(0.049)$ & $0.145^{* *}$ & $(0.031)$ & $0.181^{* *}$ & $(0.048)$ & 0.206 & $(0.193)$ \\
\hline Log of hh income & $-0.187 * *$ & $(0.014)$ & $-0.119 * *$ & $(0.008)$ & $-0.138 * *$ & $(0.012)$ & $0.118 *$ & $(0.054)$ \\
\hline Employee & -0.015 & $(0.053)$ & $-0.073^{*}$ & $(0.034)$ & -0.050 & $(0.052)$ & -0.383 & $(0.200)$ \\
\hline Self-employed & $0.195^{* *}$ & $(0.064)$ & $0.175^{* *}$ & $(0.041)$ & $0.175^{* *}$ & $(0.063)$ & -0.190 & $(0.276)$ \\
\hline Unemployed & $-0.271^{* *}$ & $(0.072)$ & $-0.176^{* *}$ & $(0.046)$ & $-0.222 * *$ & (0.069) & -0.129 & $(0.249)$ \\
\hline Urban area & $-0.187 * *$ & $(0.027)$ & $-0.197 * *$ & $(0.017)$ & $-0.184 * *$ & $(0.027)$ & 0.097 & $(0.121)$ \\
\hline No religion & $-3.313 * *$ & $(0.030)$ & $-2.986 * *$ & $(0.018)$ & $-3.158 * *$ & $(0.028)$ & $-3.158 * *$ & $(0.128)$ \\
\hline Protestant & $-0.367 * *$ & $(0.037)$ & & & & & -0.451 & $(0.182)$ \\
\hline Orthodox & $-0.574 * *$ & $(0.054)$ & & & & & -0.223 & $(0.187)$ \\
\hline Christian other & $0.761^{* *}$ & $(0.112)$ & & & & & $0.836^{* *}$ & $(0.287)$ \\
\hline Muslim & 0.241 & $(0.221)$ & & & & & 0.132 & $(0.163)$ \\
\hline Jewish & $-2.027 * *$ & $(0.538)$ & & & & & $-1.378^{*}$ & $(0.568)$ \\
\hline Immigr & & & $0.548^{* *}$ & (0.039) & $1.221^{* *}$ & $(0.129)$ & & \\
\hline Immigr*No religion & & & 0.051 & $(0.070)$ & 0.094 & $(0.116)$ & & \\
\hline Immigr*YSM6-10 & & & & & -0.235 & $(0.185)$ & -0.226 & $(0.182)$ \\
\hline Immigr*YSM11-20 & & & & & -0.271 & $(0.161)$ & -0.256 & $(0.162)$ \\
\hline Immigr*YSM20+ & & & & & $-0.496^{* *}$ & $(0.154)$ & $-0.337 *$ & $(0.170)$ \\
\hline Immigr*Language & & & & & -0.109 & $(0.115)$ & -0.165 & $(0.117)$ \\
\hline Immigr*Citizen & & & & & $-0.390 * *$ & $(0.114)$ & -0.096 & $(0.112)$ \\
\hline $\mathrm{N}$ obs & 84447 & & 91472 & & 91453 & & 7017 & \\
\hline R-squared & 0.372 & & 0.325 & & 0.363 & & 0.303 & \\
\hline
\end{tabular}

Notes. 1. Dependent variable: "how religious are you?” Measured on the scale from 1 to 10,10 indicating higher values. It is treated as a continuous variable.

2. Coefficients from OLS regressions. All regressions are estimated accounting for the population and design survey weights. Robust standard errors of the estimated coefficients are shown in parentheses.

3. The symbols $(* *)$ and $(*)$ represent statistical significance at $\mathrm{p}<.01$ and $\mathrm{p}<.05$, respectively.

4. Omitted categories of independent variables: out of the labor force; Roman Catholic.

5. Source: Authors' calculations based on the European Social Survey, 2002-2009. 
Table 3. Analysis of Religiosity: How often do you pray?

\begin{tabular}{|c|c|c|c|c|c|c|c|c|}
\hline \multirow[t]{3}{*}{ Variables } & \multirow{2}{*}{\multicolumn{2}{|c|}{$\begin{array}{c}\text { Native born } \\
(1) \\
\end{array}$}} & \multicolumn{4}{|c|}{ Native born + First generation immigrants } & \multirow{2}{*}{\multicolumn{2}{|c|}{$\begin{array}{c}\begin{array}{c}\text { First generation } \\
\text { immigrants }\end{array} \\
(4) \\
\end{array}$}} \\
\hline & & & & ) & & ) & & \\
\hline & $-1.217 * *$ & $(0.299)$ & $-0.873 * *$ & $(0.193)$ & $-1.074 * *$ & $(0.298)$ & 1.331 & (1.317) \\
\hline Age squared/100 & $2.632 * *$ & $(0.344)$ & $2.154^{* *}$ & $(0.218)$ & $2.396^{* *}$ & $(0.341)$ & -0.259 & $(1.479)$ \\
\hline Education years & $-3.612 * *$ & $(0.700)$ & $-5.463 * *$ & $(0.481)$ & $-5.883 * *$ & $(0.713)$ & $-7.285^{* *}$ & $(2.645)$ \\
\hline Education squared & $0.140^{* *}$ & $(0.024)$ & $0.190^{* *}$ & $(0.018)$ & $0.209^{* *}$ & $(0.025)$ & $0.271^{* *}$ & $(0.099)$ \\
\hline Female & $33.964 * *$ & $(1.307)$ & $37.448^{* *}$ & $(0.829)$ & $32.377 * *$ & (1.309) & $29.952 * *$ & $(5.581)$ \\
\hline $\mathrm{N}$ hh members & $8.196 * *$ & $(0.685)$ & $6.374^{* *}$ & $(0.361)$ & $8.856^{* *}$ & $(0.653)$ & $8.606^{* *}$ & (2.680) \\
\hline Married & 2.482 & $(1.781)$ & $5.153^{* *}$ & $(1.149)$ & 2.289 & $(1.772)$ & -0.728 & $(7.437)$ \\
\hline Divorced & $8.768^{* *}$ & $(2.446)$ & $10.156^{* *}$ & $(1.526)$ & $9.843^{* *}$ & $(2.422)$ & $28.490 * *$ & $(10.081)$ \\
\hline Log of hh income & $-14.540^{* *}$ & $(0.686)$ & $-10.599 * *$ & $(0.441)$ & $-10.239 * *$ & $(0.682)$ & 4.636 & $(2.843)$ \\
\hline Employee & -3.684 & (2.474) & $-11.036^{* *}$ & (1.734) & $-5.026^{*}$ & (2.459) & -7.014 & (9.973) \\
\hline Self-employed & $6.879 *$ & (3.095) & -0.057 & $(2.158)$ & $6.448^{*}$ & (3.078) & -5.808 & (13.505) \\
\hline Unemployed & $-9.135 * *$ & (3.421) & $-10.341^{* *}$ & $(2.356)$ & -5.900 & (3.356) & -6.665 & (12.982) \\
\hline Urban area & $-12.399 * *$ & $(1.418)$ & $-7.549 * *$ & $(0.881)$ & $-12.275^{* *}$ & $(1.420)$ & 7.994 & $(6.582)$ \\
\hline No religion & $-104.006^{* *}$ & (1.509) & $-92.530 * *$ & $(0.805)$ & $-90.848^{* *}$ & (1.254) & $-111.860^{* *}$ & $(6.942)$ \\
\hline Protestant & $-27.865^{* *}$ & (2.318) & & & & & -18.223 & (12.108) \\
\hline Orthodox & $-47.826 * *$ & (3.611) & & & & & $-35.692 * *$ & (11.779) \\
\hline Christian other & $57.195^{* *}$ & (7.199) & & & & & $84.811^{* *}$ & (17.117) \\
\hline Muslim & -9.427 & (14.092) & & & & & $51.067 * *$ & (10.915) \\
\hline Jewish & -22.556 & (31.594) & & & & & $-88.199 * *$ & (29.981) \\
\hline Immigr & & & $32.604 * *$ & $(2.610)$ & $75.766^{* *}$ & (8.391) & & \\
\hline Immigr*No religion & & & $-14.438^{* *}$ & (3.289) & $-26.878^{* *}$ & (5.525) & & \\
\hline Immigr*YSM6-10 & & & & & $-20.451^{*}$ & (10.186) & $-21.233^{*}$ & (9.639) \\
\hline Immigr*YSM11-20 & & & & & $-28.933^{* *}$ & $(9.257)$ & $-29.397 * *$ & $(8.700)$ \\
\hline Immigr*YSM20+ & & & & & $-18.440^{*}$ & (8.912) & $-20.064^{*}$ & $(9.290)$ \\
\hline Immigr*Language & & & & & -3.644 & (6.642) & -5.584 & $(6.466)$ \\
\hline Immigr*Citizen & & & & & -10.848 & (6.268) & 5.219 & (6.004) \\
\hline $\mathrm{N}$ obs & 83865 & & 90849 & & 90831 & & 6976 & \\
\hline R-squared & 0.223 & & 0.198 & & 0.208 & & 0.211 & \\
\hline
\end{tabular}

Notes. 1. Dependent variable: how often do you pray? Measured on the scale from 0 to 365, 0 stands for "never", 365 stands for "every day". It is treated as a continuous variable.

2. Coefficients from OLS regressions. All regressions are estimated accounting for the population and design survey weights.

Robust standard errors of the estimated coefficients are shown in parentheses.

3. The symbols $(* *)$ and $(*)$ represent statistical significance at $\mathrm{p}<.01$ and $\mathrm{p}<.05$, respectively.

4. Omitted categories of independent variables: out of the labor force; Roman Catholic.

5. Source: Authors’ calculations based on the European Social Survey, 2002-2009. 
Table 4. Analysis of Religiosity: How often do you attend religious services?

\begin{tabular}{|c|c|c|c|c|c|c|c|c|}
\hline \multirow[t]{3}{*}{ Variables } & \multirow{2}{*}{\multicolumn{2}{|c|}{$\begin{array}{c}\text { Native born } \\
\text { (1) } \\
\end{array}$}} & \multicolumn{4}{|c|}{$\begin{array}{c}\text { Native born + First generation } \\
\text { immigrants }\end{array}$} & \multirow{2}{*}{\multicolumn{2}{|c|}{$\begin{array}{c}\begin{array}{c}\text { First generation } \\
\text { immigrants }\end{array} \\
(4) \\
\end{array}$}} \\
\hline & & & & & $(3$ & & & \\
\hline & $-0.267 * *$ & $(0.069)$ & $-0.334 * *$ & $(0.051)$ & $-0.247^{* *}$ & $(0.073)$ & -0.263 & $(0.556)$ \\
\hline Age squared/100 & $0.494 * *$ & $(0.085)$ & $0.624 * *$ & $(0.060)$ & $0.448^{* *}$ & $(0.089)$ & 0.499 & $(0.630)$ \\
\hline Education years & -0.311 & $(0.181)$ & $-1.017^{* *}$ & $(0.157)$ & $-1.337 * *$ & $(0.275)$ & $-5.271^{*}$ & $(2.072)$ \\
\hline Education squared & $0.013^{*}$ & $(0.006)$ & $0.038 * *$ & $(0.006)$ & $0.046^{* *}$ & $(0.010)$ & $0.191^{*}$ & $(0.078)$ \\
\hline Female & $2.607^{* *}$ & $(0.335)$ & $3.051^{* *}$ & $(0.205)$ & $1.770^{* *}$ & $(0.364)$ & -3.395 & $(2.050)$ \\
\hline $\mathrm{N}$ hh members & $1.705^{* *}$ & $(0.184)$ & $1.869 * *$ & $(0.103)$ & $1.896 * *$ & $(0.182)$ & 1.487 & (1.013) \\
\hline Married & -0.175 & $(0.428)$ & -0.496 & $(0.307)$ & -0.103 & $(0.444)$ & 1.802 & $(2.684)$ \\
\hline Divorced & $-1.444 * *$ & $(0.520)$ & $-1.928 * *$ & $(0.394)$ & $-1.561 * *$ & $(0.550)$ & -0.649 & (3.120) \\
\hline Log of hh income & $-2.898 * *$ & $(0.169)$ & $-2.499 * *$ & $(0.110)$ & $-1.768^{* *}$ & (0.199) & -0.915 & $(1.061)$ \\
\hline Employee & $-2.235^{* *}$ & $(0.627)$ & $-4.104 * *$ & $(0.549)$ & $-2.919 * *$ & $(0.710)$ & -5.856 & $(5.383)$ \\
\hline Self-employed & 0.070 & $(0.871)$ & $-2.854 * *$ & $(0.638)$ & -0.325 & $(0.925)$ & -4.902 & (5.885) \\
\hline Unemployed & $-4.359 * *$ & $(0.722)$ & $-4.960 * *$ & $(0.659)$ & $-3.278 * *$ & $(0.851)$ & -2.307 & $(6.651)$ \\
\hline Urban area & $-1.467 * *$ & $(0.357)$ & $-1.118^{* *}$ & $(0.225)$ & $-1.646^{* *}$ & $(0.383)$ & 2.150 & $(2.362)$ \\
\hline No religion & $-20.668 * *$ & $(0.334)$ & $-16.374^{* *}$ & $(0.184)$ & $-15.955^{* *}$ & $(0.274)$ & $-19.592 * *$ & $(2.015)$ \\
\hline Protestant & $-9.755^{* *}$ & $(0.510)$ & & & & & 3.145 & $(4.761)$ \\
\hline Orthodox & $-16.230 * *$ & $(0.787)$ & & & & & $-9.353 * *$ & (3.359) \\
\hline Christian other & $15.770^{* *}$ & $(2.863)$ & & & & & $30.618^{* *}$ & $(7.711)$ \\
\hline Muslim & 0.979 & (6.396) & & & & & $15.171^{* *}$ & $(5.015)$ \\
\hline Jewish & $-11.356^{* *}$ & (3.837) & & & & & -2.166 & (11.960) \\
\hline Immigr & & & $3.129 * *$ & $(0.784)$ & $15.409 * *$ & (3.889) & & \\
\hline Immigr*No religion & & & $-2.397 * *$ & $(0.839)$ & $-7.887 * *$ & (1.819) & & \\
\hline Immigr*YSM6-10 & & & & & -4.049 & (3.366) & -4.002 & (3.210) \\
\hline Immigr*YSM11-20 & & & & & -3.131 & (3.409) & -2.655 & (3.319) \\
\hline Immigr*YSM20+ & & & & & -1.205 & (3.280) & -1.210 & (3.285) \\
\hline Immigr*Language & & & & & -3.702 & $(2.502)$ & -3.180 & (2.259) \\
\hline Immigr*Citizen & & & & & -3.055 & (2.210) & 0.319 & $(2.278)$ \\
\hline $\mathrm{N}$ obs & 84447 & & 91472 & & 91453 & & 7017 & \\
\hline R-squared & 0.139 & & 0.103 & & 0.103 & & 0.105 & \\
\hline
\end{tabular}

Notes. 1. Dependent variable: how often do you attend religious services? Measured on the scale from 0 to 365, 0 stands for "never", 365 stands for "every day". It is treated as a continuous variable.

2. Coefficients from OLS regressions. All regressions are estimated accounting for the population and design survey weights. Robust standard errors of the estimated coefficients are shown in parentheses.

3 . The symbols $(* *)$ and $(*)$ represent statistical significance at $\mathrm{p}<.01$ and $\mathrm{p}<.05$, respectively.

4. Omitted categories of independent variables: out of the labor force; Roman Catholic.

5. Source: Authors' calculations based on the European Social Survey, 2002-2009. 
Table 5. Differences in Religiosity by Sub-group of Denomination and Immigrant Type

\begin{tabular}{|c|c|c|c|c|c|c|c|c|c|c|c|}
\hline \multirow{3}{*}{$\begin{array}{c}\begin{array}{c}\text { Sub- } \\
\text { sample }\end{array} \\
\text { No religion }\end{array}$} & \multirow{3}{*}{$\begin{array}{l}\text { Dep. Variable } \\
\text { How religious }\end{array}$} & \multicolumn{10}{|c|}{ Native born + First generation } \\
\hline & & \multicolumn{2}{|c|}{ Immigr } & \multicolumn{2}{|c|}{ Immigr*YSM6-10 } & \multicolumn{2}{|c|}{ Immigr*YSM11-20 } & \multicolumn{2}{|c|}{ Immigr*YSM20+ } & \multirow{2}{*}{$\begin{array}{l}\text { N obs } \\
39790\end{array}$} & \multirow{2}{*}{$\begin{array}{c}\begin{array}{c}\text { R- } \\
\text { squared }\end{array} \\
0.033\end{array}$} \\
\hline & & $1.278^{* * *}$ & $(0.253)$ & -0.179 & $(0.381)$ & -0.027 & $(0.305)$ & -0.314 & $(0.293)$ & & \\
\hline & Praying & $24.571^{* * *}$ & (9.507) & -8.211 & $(9.856)$ & -5.624 & $(9.264)$ & -0.189 & $(9.765)$ & 49674 & 0.028 \\
\hline & Attending & $3.263^{* *}$ & (1.605) & -2.193 & (1.937) & -1.385 & $(1.870)$ & $-2.975 *$ & $(1.658)$ & 39686 & 0.005 \\
\hline Roman & How religious & $1.488^{* * *}$ & $(0.243)$ & -0.347 & $(0.289)$ & -0.365 & $(0.261)$ & $-0.637 * *$ & $(0.266)$ & 27,598 & 0.086 \\
\hline \multirow[t]{2}{*}{ Catholic } & Praying & $90.708^{* * *}$ & (17.330) & -2.093 & (20.632) & $-33.928 *$ & (18.783) & $-41.906^{* *}$ & $(17.064)$ & 27,334 & 0.147 \\
\hline & Attending & $18.335^{* * *}$ & (5.999) & -5.507 & (5.321) & $-11.085^{*}$ & (5.768) & $-10.308^{* *}$ & (5.025) & 27,655 & 0.083 \\
\hline \multirow[t]{3}{*}{ Protestant } & How religious & $0.915^{*}$ & $(0.490)$ & -0.450 & $(0.557)$ & -0.787 & $(0.502)$ & -0.394 & $(0.518)$ & 16,021 & 0.059 \\
\hline & Praying & 27.537 & $(27.964)$ & 19.000 & (36.355) & -5.868 & (35.552) & 24.736 & (35.607) & 15,938 & 0.068 \\
\hline & Attending & 9.947 & (6.330) & 0.085 & $(6.601)$ & -6.646 & $(7.490)$ & 11.570 & $(10.718)$ & 16,039 & 0.054 \\
\hline \multirow[t]{3}{*}{ Orthodox } & How religious & 0.361 & $(0.348)$ & $0.949 *$ & $(0.490)$ & 0.184 & $(0.475)$ & -0.309 & $(0.468)$ & 5,254 & 0.073 \\
\hline & Praying & $56.261 * *$ & (24.314) & -16.500 & (30.978) & -20.121 & (28.873) & 10.660 & (32.175) & 5,114 & 0.119 \\
\hline & Attending & 4.022 & (4.144) & 1.902 & $(5.794)$ & 6.748 & $(7.327)$ & 1.542 & $(9.726)$ & 5,244 & 0.041 \\
\hline \multirow{3}{*}{$\begin{array}{l}\text { Christian } \\
\text { other }\end{array}$} & How religious & 0.516 & $(0.522)$ & -0.182 & $(0.618)$ & -0.088 & $(0.715)$ & -0.515 & $(0.672)$ & 1,638 & 0.082 \\
\hline & Praying & 49.803 & (32.936) & -43.294 & $(47.060)$ & -45.053 & (43.895) & -51.715 & (39.576) & 1,630 & 0.119 \\
\hline & Attending & -10.408 & (13.834) & -4.615 & (13.016) & 0.532 & (18.429) & -0.243 & $(15.291)$ & 1,642 & 0.088 \\
\hline \multirow[t]{3}{*}{ Muslim } & How religious & $0.821^{*}$ & $(0.439)$ & $-0.840 * *$ & $(0.423)$ & -0.592 & $(0.375)$ & $-0.795 * *$ & $(0.391)$ & 1,084 & 0.122 \\
\hline & Praying & $63.041^{* *}$ & $(28.516)$ & $-70.196 * *$ & (28.191) & $-55.576 * *$ & (25.964) & $-51.379 * *$ & (25.839) & 1,073 & 0.125 \\
\hline & Attending & 7.477 & (18.508) & -11.847 & $(13.967)$ & 1.952 & (15.059) & 9.334 & (14.408) & 1,077 & 0.070 \\
\hline \multirow[t]{3}{*}{ Jewish } & How religious & $3.399 * *$ & (1.609) & -1.446 & $(1.502)$ & -2.100 & (1.773) & -1.307 & $(1.944)$ & 68 & 0.592 \\
\hline & Praying & 24.400 & (105.942) & -17.520 & (95.500) & $-179.907^{*}$ & $(94.060)$ & -95.345 & (103.995) & 68 & 0.403 \\
\hline & Attending & 30.594 & (50.354) & $92.665^{* *}$ & (39.754) & 19.087 & (26.404) & 42.736 & (30.143) & 68 & 0.516 \\
\hline
\end{tabular}

Notes. 1. Each line represents a separate regression; where the first row's heading defines the sub-sample (for example, pooled sample of individuals with no religious denomination); and second row's heading defines the dependent variable (for example, "how religious”).

2. Coefficients from OLS regressions. All regressions include the full set of individual-specific and immigrantspecific characteristics as in Tables 2-4, and are estimated accounting for the population and design survey weights. Robust standard errors of the estimated coefficients are shown in parentheses.

3. The symbols $(* * *),(* *)$, and $(*)$ represent statistical significance at $\mathrm{p}<.01, \mathrm{p}<.05$, and $\mathrm{p}<.10$, respectively.

4. Source: Authors’ calculations based on the European Social Survey, 2002-2009. 
Table 6. Country Characteristics as Determinants of Religiosity

\begin{tabular}{|c|c|c|c|c|c|c|c|}
\hline \multirow{16}{*}{ 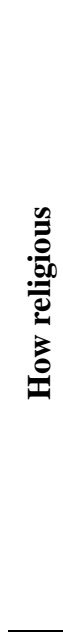 } & \multirow{2}{*}{$\begin{array}{l}\text { Variables } \\
\text { Belonging major }\end{array}$} & \multicolumn{2}{|c|}{ (1) Native born } & \multicolumn{2}{|c|}{ (2) Native born and Immigrants } & \multicolumn{2}{|c|}{ (3) Immigrants } \\
\hline & & $-0.128 * *$ & $(0.057)$ & $-0.128 * *$ & $(0.054)$ & 0.162 & $(0.183)$ \\
\hline & Relig fragm & $-0.839 * * *$ & $(0.058)$ & $-0.809 * * *$ & $(0.056)$ & $-0.656 * *$ & $(0.294)$ \\
\hline & Relig freedom & $0.349 * * *$ & $(0.093)$ & $0.373^{* * *}$ & $(0.088)$ & $1.044 * * *$ & $(0.335)$ \\
\hline & Social attitudes & $0.647 * * *$ & $(0.049)$ & $0.694^{* * *}$ & $(0.048)$ & $1.373^{* * *}$ & $(0.283)$ \\
\hline & GDP & $-0.008 * * *$ & $(0.001)$ & $-0.007 * * *$ & $(0.001)$ & $0.011 * *$ & $(0.005)$ \\
\hline & Immigr & & & $1.063^{* * *}$ & $(0.286)$ & & \\
\hline & Immigr*YSM6-10 & & & -0.220 & $(0.186)$ & -0.135 & $(0.189)$ \\
\hline & Immigr*YSM11-20 & & & -0.233 & $(0.157)$ & -0.200 & $(0.170)$ \\
\hline & Immigr*YSM20+ & & & $-0.577 * * *$ & $(0.135)$ & $-0.363 * *$ & $(0.177)$ \\
\hline & Immigr*Belonging major at origin & & & $-0.252 * *$ & $(0.117)$ & -0.134 & $(0.160)$ \\
\hline & Immigr*Relig fragm at origin & & & $-0.489 * *$ & $(0.203)$ & -0.342 & $(0.223)$ \\
\hline & Immigr*Relig freedom at origin & & & $0.832 * * *$ & $(0.225)$ & $0.688 * * *$ & $(0.238)$ \\
\hline & Immigr*Social attitudes at origin & & & 0.271 & $(0.197)$ & 0.231 & $(0.207)$ \\
\hline & Immigr*GDP at origin & & & $-0.021 * * *$ & $(0.004)$ & $-0.027 * * *$ & $(0.004)$ \\
\hline & Immigr*Communist at origin & & & $-0.744 * * *$ & $(0.138)$ & $-0.634 * * *$ & $(0.168)$ \\
\hline \multirow{15}{*}{ 胞 } & Belonging major & $-30.930 * * *$ & (3.254) & $-31.352 * * *$ & (3.105) & $-27.319 * *$ & $(10.722)$ \\
\hline & Relig fragm & $-57.739 * * *$ & (3.299) & $-59.481 * * *$ & (3.224) & $-87.250 * * *$ & $(16.458)$ \\
\hline & Relig freedom & $81.575 * * *$ & $(4.176)$ & $77.285 * * *$ & $(4.077)$ & $48.288 * * *$ & $(17.976)$ \\
\hline & Social attitudes & $44.220 * * *$ & $(2.785)$ & $47.009 * * *$ & $(2.746)$ & $86.507 * * *$ & (15.339) \\
\hline & GDP & $-0.461^{* * *}$ & $(0.056)$ & $-0.406 * * *$ & $(0.056)$ & 0.352 & $(0.257)$ \\
\hline & Immigr & & & $48.640 * * *$ & (15.848) & & \\
\hline & Immigr*YSM6-10 & & & -10.437 & $(9.451)$ & -9.671 & (9.651) \\
\hline & Immigr*YSM11-20 & & & -11.472 & $(8.245)$ & $-15.611^{*}$ & $(8.740)$ \\
\hline & Immigr*YSM20+ & & & -10.609 & $(7.746)$ & -10.874 & $(9.461)$ \\
\hline & Immigr*Belonging major at origin & & & 3.601 & $(6.826)$ & -2.229 & (10.178) \\
\hline & Immigr*Relig fragm at origin & & & -2.002 & $(10.981)$ & 9.318 & $(11.866)$ \\
\hline & Immigr*Relig freedom at origin & & & $37.399 * * *$ & (12.593) & $29.597 * *$ & $(13.218)$ \\
\hline & Immigr*Social attitudes at origin & & & 16.767 & $(10.485)$ & 12.114 & $(10.989)$ \\
\hline & Immigr*GDP at origin & & & $-1.726 * * *$ & $(0.216)$ & $-1.995 * * *$ & $(0.237)$ \\
\hline & Immigr*Communist at origin & & & $-54.515 * * *$ & $(7.302)$ & $-42.022 * * *$ & (7.951) \\
\hline \multirow{15}{*}{ } & Belonging major & $-2.486 * * *$ & $(0.836)$ & $-3.170 * * *$ & $(0.828)$ & -4.490 & (3.528) \\
\hline & Relig fragm & $-16.193 * * *$ & $(0.774)$ & $-17.344^{* * *}$ & $(0.822)$ & $-37.865 * * *$ & (7.971) \\
\hline & Relig freedom & $12.497 * * *$ & $(1.002)$ & $11.630 * * *$ & $(1.046)$ & 9.493 & (5.875) \\
\hline & Social attitudes & $11.180 * * *$ & $(0.714)$ & $12.359 * * *$ & $(0.763)$ & $34.566 * * *$ & (6.904) \\
\hline & GDP & $-0.159 * * *$ & $(0.015)$ & $-0.129 * * *$ & $(0.016)$ & 0.165 & $(0.121)$ \\
\hline & Immigr & & & 3.902 & $(5.814)$ & & \\
\hline & Immigr*YSM6-10 & & & -1.989 & (3.297) & -1.265 & (3.239) \\
\hline & Immigr*YSM11-20 & & & 0.099 & $(3.410)$ & 1.430 & (3.307) \\
\hline & Immigr*YSM20+ & & & -0.707 & $(3.320)$ & 1.378 & (3.272) \\
\hline & Immigr*Belonging major at origin & & & -0.943 & $(2.375)$ & -2.552 & (3.705) \\
\hline & Immigr*Relig fragm at origin & & & -1.349 & $(3.000)$ & 0.283 & (3.224) \\
\hline & Immigr*Relig freedom at origin & & & 4.799 & $(5.255)$ & 4.989 & $(5.300)$ \\
\hline & Immigr*Social attitudes at origin & & & $12.290 * * *$ & $(3.706)$ & $13.314^{* * *}$ & (4.283) \\
\hline & Immigr*GDP at origin & & & $-0.362 * * *$ & $(0.094)$ & $-0.374 * * *$ & $(0.094)$ \\
\hline & Immigr*Communist at origin & & & $-13.735^{* * *}$ & $(2.895)$ & $-10.045^{* * *}$ & $(2.697)$ \\
\hline
\end{tabular}

Notes.1. Dependent variables are indicated in the first column.

2. Coefficients from OLS regressions. All regressions include the full set of individual-specific and immigrant-specific characteristics as in Tables 2-4, and are estimated accounting for the population and design survey weights. Robust standard errors of the estimated coefficients are shown in parentheses.

3. The symbols $(* *)$ and $(*)$ represent statistical significance at $\mathrm{p}<.01$ and $\mathrm{p}<.05$, respectively.

4. Source: Authors’ calculations based on the European Social Survey, 2002-2009. 


\section{Appendix Table A1. Sample Description}

\begin{tabular}{|c|c|c|c|c|c|c|c|c|}
\hline $\begin{array}{l}\text { Destination } \\
\text { Country }\end{array}$ & $\begin{array}{c}\mathrm{N} \text { Obs } \\
\text { Native born }\end{array}$ & $\begin{array}{c}\text { N Obs } \\
\text { First- } \\
\text { generation } \\
\text { immigrants }\end{array}$ & $\begin{array}{c}\text { Percent of } \\
\text { Immigrants } \\
\text { with over } \\
20 \text { years of } \\
\text { residence }\end{array}$ & $\begin{array}{c}\mathrm{N} \text { of } \\
\text { immigrant } \\
\text { countries } \\
\text { of origin }\end{array}$ & $\begin{array}{c}\text { Largest } \\
\text { immigrant } \\
\text { origin } \\
\text { country }\end{array}$ & $\begin{array}{l}\text { Largest } \\
\text { religion }\end{array}$ & $\begin{array}{c}\text { First largest } \\
\text { religion } \\
\text { among } \\
\text { immigrants }^{+}\end{array}$ & $\begin{array}{c}\text { Second } \\
\text { largest } \\
\text { religion } \\
\text { among } \\
\text { immigrants }\end{array}$ \\
\hline Austria & 2971 & 228 & 41,20 & 16 & Germany & Catholic & Catholic & Islam \\
\hline Belgium & 4169 & 381 & 48,53 & 18 & France & Catholic & Catholic & Islam \\
\hline Switzerland & 3423 & 943 & 44,86 & 39 & Germany & Catholic & Catholic & Protestant \\
\hline Czech Republic & 2047 & 68 & 82,76 & 3 & Slovakia & Atheist & Catholic & Oth. Christian \\
\hline Germany & 6485 & 554 & 31,55 & 26 & Russia & Catholic & Catholic & Islam \\
\hline Denmark & 4135 & 191 & 38,14 & 15 & Turkey & Protestant & Islam & Protestant \\
\hline Estonia & 1542 & 411 & 85,11 & 11 & Russia & Protestant & Orthodox & Protestant \\
\hline Spain & 3540 & 299 & 7,14 & 21 & Morocco & Catholic & Catholic & Islam \\
\hline Finland & 4551 & 87 & 12,75 & 4 & Russia & Protestant & Protestant & Orthodox \\
\hline France & 3471 & 297 & 62,50 & 15 & Algeria & Catholic & Catholic & Islam \\
\hline The UK & 4916 & 413 & 37,28 & 24 & India & Protestant & Catholic & Islam \\
\hline Greece & 2177 & 255 & 8,40 & 10 & Albania & Orthodox & Orthodox & Islam \\
\hline Hungary & 3407 & 45 & 22,92 & 4 & Romania & Catholic & Catholic & Protestant \\
\hline Ireland & 3504 & 227 & 24,26 & 11 & The UK & Catholic & Catholic & Protestant \\
\hline Luxembourg & 778 & 544 & 38,00 & 19 & Portugal & Catholic & Catholic & Oth.Christian \\
\hline The Netherlands & 5014 & 428 & 48,97 & 12 & Surinam & Atheist & Islam & Catholic \\
\hline Norway & 5320 & 311 & 30,75 & 19 & Sweden & Protestant & Islam & Protestant \\
\hline Poland & 4888 & 31 & 57,14 & 3 & Germany & Catholic & Catholic & Islam \\
\hline Portugal & 3127 & 151 & 31,13 & 8 & Brazil & Catholic & Catholic & Protestant \\
\hline Russia & 2967 & 148 & 46,10 & 11 & Ukraine & Orthodox & Orthodox & Islam \\
\hline Sweden & 4976 & 570 & 48,96 & 23 & Finland & Protestant & Islam & Protestant \\
\hline Slovenia & 2775 & 159 & 74,85 & 5 & Bosnia & Catholic & Catholic & Orthodox \\
\hline Slovakia & 2530 & 47 & 57,45 & 3 & Czech Rep. & Catholic & Catholic & Oth.Christian \\
\hline Ukraine & 1734 & 229 & 73,58 & 10 & Russia & Orthodox & Orthodox & Islam \\
\hline Total & 84447 & 7017 & & & & & & \\
\hline
\end{tabular}

Notes. 1. Counted are only the observations of the sample restricted for the analysis, and for which full information on all socio-economic characteristics is available. As income is missing for about 20 percent of the sample, the original ESS data contains considerably more observations. There is, however, no systematic difference between individuals who report and do not report their income in terms of age, gender, education, or employment status. The largest numbers of both native and foreign-born income non-reporters are in Portugal (12\%), Austria (10\%), and Spain (10\%). Number of immigrant countries of origin: counted are only countries represented by more than 3 immigrants.

2. Source: Authors' calculations based on the European Social Survey, 2002-2009, and Association of Religious Data Archive, 2005.

+ "Without a religious affiliation" is the largest group among immigrants in the following countries: Austria, Belgium, Switzerland, Germany, Denmark, Estonia, Finland, France, the UK, Ireland, the Netherlands, Norway, Sweden, Slovakia, Slovenia. 
Appendix Table A2. Definition of Variables Used in the Regression Analysis and Data Sources 


\section{Dependent variables}

How religious are you? How religious are you? An index from 0 to 10,

0 meaning not religious at all, 10 - very religious

Attending religious How often attend religious services apart from special occasions?

services 365-every day

100-more than once a week

52-once a week

15-at least once a month

4-only on special holy days

1-less often

0 -never

Praying frequency How often do you pray?

365-every day

100-more than once a week

52-once a week

15-at least once a month

4-only on special holy days

1-less often

0 -never

\section{Individual socio-economic characteristics}

Age

Age squared/100

Female

Education years

Education squared

$\mathrm{N}$ hh members

Log of hh income

Married

Divorced

Employee

Self-employed

Unemployed

Current religious

denomination:

Roman Catholic

Protestant

Orthodox

Other Christian

Muslim

Jewish

No religion

Urban area
Age, ranges from 16 to 70

Age squared, divided by 100

A dichotomous variable equal to 1 if female, 0 if male

Years of full-time education completed, ranges from 0 to 25

Years of full-time education completed squared

Number of people living regularly as member of household

Logarithm of monthly total household income, constructed from a categorical variable using a midpoint level. I.e., if income level is between $€ 1800$ and $€ 3600$, the value of $€ 2700$ is assigned. The value of the highest category is its lower bound multiplied by 1,5. Values in national currencies are converted into Euro using average exchange rate of the survey year.

A dichotomous variable equal to 1 if married or in a civil partnership, 0 otherwise

A dichotomous variable equal to 1 if divorced, separated, or widowed, 0 otherwise. Benchmark category: single (never married)

A dichotomous variable equal to 1 if works as an employee, zero otherwise

A dichotomous variable equal to 1 if self-employed or working in family business

A dichotomous variable equal to 1 if unemployed in the past 7 days, actively or inactively looking for a job. Benchmark category: not in the labor force (studying full-time/permanently sick/disabled/retired)

A dichotomous variable equal to 1 if an individual belongs to any of the mentioned categories, 0 otherwise

A dichotomous variable equal to 1 if an individual lives in urban area (city, suburb, or town), and 0 if in a village or a countryside farm

\section{Immigrant -specific characteristics}


Length of stay:

YSM6-10

YSM10-20

YSM20+

Citizen

Language
How long ago came to live to this country:

1 if between 6 and 10 years ago

1 if between 11 and 20 years ago

1 if over 20 years ago (Benchmark category: five years and less)

A dichotomous variable equal to 1 if an individual is a citizen of the country of residence, 0 otherwise

A dichotomous variable equal to 1 if an individual speaks any official language of a country of residence at home as the first language choice, 0 otherwise

\section{$\underline{\text { Religion and Country-Specific Variables }}$}

Belong major

Religious fragmentation

Religious freedom (recoded from the original)

Social attitudes

Belong major origin

Religious fragmentation

at origin

Religious freedom at origin

Social attitudes at origin

GDP, GDP at origin

Communist at origin
A dichotomous variable equal to 1 if an individual belongs to the religion which is the main religion of the country, 0 otherwise

Index of religious fragmentation (Alesina, Devleeschauwer, Easterly, Kurlat and Wacziarg, 2003; Iannaccone, 1998). Constructed according to the formula:

$$
\mathrm{RF}_{\mathrm{i}}=1-\sum_{k} s_{k i}^{2} \text {, }
$$

where $s$ is a share of $k$ religion denominations in country $i$ (we use first five denominations). This index is also known as one minus Herfindahl index, and measures the probability that two randomly drawn individuals in country $i$ belong to different religions, which also means that higher values of the index represent higher religious fragmentation, hence, heterogeneity.

Freedom of religion. Category responses are the following: $0=$ Does not exist. $0.333=$ Limited and/or rights not protected or restricted. $0.666=$ Law/Constitution provides for freedom of religion and the Government generally respects this right in practice, but some problems exist. $1=$ Law/Constitution provides for freedom of religion and the Government 'generally respects' this right in practice.

The index is constructed on the basis of the following questions:

Societal attitudes towards other or non-traditional religions; conversion to other religions? Do attitudes and/or clerical edits discourage proselytizing? Do established or existing religions try to shut out new religions in any way? Extent of assertive religious movements in the country? 0 - low social regulation (tolerant societies); 1 - medium; 2 - high

Similarly defined variables, for immigrants only and for their countries of origin

\section{SOURCES:}

GDP PPP-adjusted per capita values

Jowell R. and the Central Co-ordinating Team. 2009. “European Social Survey: Technical Report”. London: Centre for Comparative Social Surveys. City University. Available at: http://www.europeansocialsurvey.org

Association of Religious Data Archives International Religious Freedom Data, 2005. Available at: http://www.thearda.com/ Archive/CrossNational.asp

Grim, Brian J. and Roger Finke (2006). "International Religion Indexes: Government Regulation, Government Favouritism, and Social Regulation of Religion." Interdisciplinary Journal of Research on Religion.

World Bank Development Indicators (WBDI).

World Bank, 2006. World Bank Development Indicators Database. Available at: http://www.world bank.org . Accessed: March 2010. 


\section{Appendix Table A3. Descriptive Statistics}

\begin{tabular}{|c|c|c|c|c|}
\hline \multirow[t]{2}{*}{ Variable } & \multicolumn{2}{|c|}{ Native born } & \multicolumn{2}{|c|}{ Immigrants } \\
\hline & Mean & St.Dev. & Mean & St.Dev. \\
\hline How religious are you? & 4,47 & 2,91 & $5,15 * *$ & 3,05 \\
\hline Attending religious services & 12,20 & 32,34 & $14,63^{* *}$ & 41,40 \\
\hline Praying frequency & 76,72 & 136,57 & $106,53 * *$ & 153,73 \\
\hline Age & 44,10 & 14,68 & 43,55 & 13,75 \\
\hline Age squared/100 & 21,61 & 12,99 & $20,85^{*}$ & 12,37 \\
\hline Female & 0,52 & 0,50 & $0,53^{*}$ & 0,50 \\
\hline Education years & 12,54 & 3,79 & $12,63^{*}$ & 4,34 \\
\hline Education squared & 171,65 & 101,16 & $178,44^{* *}$ & 116,99 \\
\hline $\mathrm{N}$ hh members & 2,83 & 1,40 & 2,83 & 1,44 \\
\hline Log of hh income & 7,32 & 1,06 & 7,38 & 1,05 \\
\hline Married & 0,55 & 0,50 & $0,58 * *$ & 0,49 \\
\hline Divorced & 0,15 & 0,36 & $0,17 * *$ & 0,38 \\
\hline Employee & 0,77 & 0,42 & 0,77 & 0,42 \\
\hline Unemployed & 0,05 & 0,23 & $0,08 * *$ & 0,27 \\
\hline Self-employed & 0,11 & 0,31 & $0,09 * *$ & 0,29 \\
\hline Out of the labour force & 0,07 & 0,25 & $0,06 * *$ & 0,24 \\
\hline Urban area & 0,61 & 0,49 & $0,75^{* *}$ & 0,43 \\
\hline YSM6-10 & 0,00 & 0,00 & $0,14^{* *}$ & 0,35 \\
\hline YSM10-20 & 0,00 & 0,00 & $0,23 * *$ & 0,42 \\
\hline YSM20+ & 0,00 & 0,00 & $0,46 * *$ & 0,50 \\
\hline Citizen & 1,00 & 0,00 & $0,50 * *$ & 0,50 \\
\hline Language & 0,95 & 0,21 & $0,69 * *$ & 0,46 \\
\hline Roman Catholic & 0,31 & 0,46 & $0,25 * *$ & 0,43 \\
\hline Protestant & 0,18 & 0,39 & $0,09 * *$ & 0,28 \\
\hline Orthodox & 0,05 & 0,22 & $0,11^{* *}$ & 0,31 \\
\hline Muslim & 0,00 & 0,05 & $0,12 * *$ & 0,32 \\
\hline Jewish & 0,00 & 0,02 & $0,00 * *$ & 0,06 \\
\hline Other Christian & 0,02 & 0,13 & $0,04^{* *}$ & 0,19 \\
\hline No religion & 0,44 & 0,50 & $0,39 * *$ & 0,49 \\
\hline Belong major & 0,50 & 0,50 & $0,31 * *$ & 0,46 \\
\hline Religious fragmentation & 0,49 & 0,24 & $0,54 * *$ & 0,25 \\
\hline Religious freedom & 0,77 & 0,19 & $0,75^{*}$ & 0,18 \\
\hline Social attitudes & 0,76 & 0,28 & $0,74 *$ & 0,33 \\
\hline GDP /1000 & 31,04 & 17,31 & $37,51^{* *}$ & 18,13 \\
\hline Belong major origin & & & 0,42 & 0,49 \\
\hline Religious fragm. origin & & & 0,46 & 0,26 \\
\hline Religious freedom origin & & & 0,63 & 0,27 \\
\hline Social attitudes origin & & & 0,80 & 0,32 \\
\hline Former communist & & & 0,34 & 0,47 \\
\hline GDP /1000 at origin & & & 15,07 & 15,47 \\
\hline Sample size & 84447 & & 7017 & \\
\hline
\end{tabular}

Notes.1. The sample includes males and females aged 16 to 70 . Native-born without citizenship, as well as immigrants with unknown country of birth are excluded from the sample. Native-born with one or both foreignborn parents are excluded. Individuals with "other religion" or missing religious belonging are also excluded. 2. The symbols $(* *)$ and $(*)$ represent statistical significance of $1 \%$ and $5 \%$ respectively of differences of means of individual characteristics, based on a t-test for differences of sample means.

3. Source: Authors' calculations. 